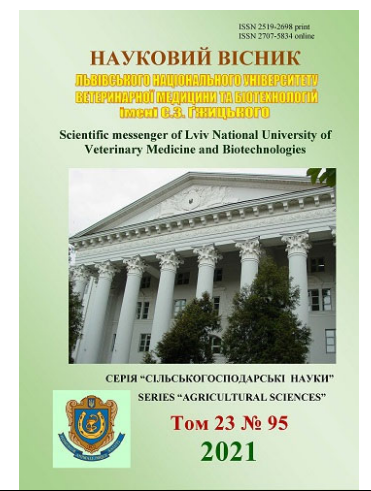

Науковий вісник Яьвівського національного університету ветеринарної медицини та біотехнологій імені С.3. Гжицького. Серія: Сільськогосподарські науки

\author{
Scientific Messenger of Lviv National University
} of Veterinary Medicine and Biotechnologies. Series: Agricultural sciences

\title{
Assessment of the quality of pond waters of Lviv region and prospects for the use of phytoplankton biomass in these reservoirs
}

\author{
N. A. Lytvyn, O. P. Rudenko, B. V. Gutyj \\ Stepan Gzhytskyi National University of Veterinary Medicine and Biotechnologies Lviv, Ukraine
}

Article info

Received 24.05.2021

Received in revised form 28.06.2021

Accepted 29.06.2021

Stepan Gzhytskyi National University of Veterinary Medicine and Biotechnologies Lviv, Pekarska Str., 50, Lviv, 79010, Ukraine Tel.: +38-096-813-07-93 E-mail: rudenko.olga86@gmail.com
Lytvyn, N. A., Rudenko, O. P., \& Gutyj, B. V. (2021). Assessment of the quality of pond waters of Lviv region and prospects for the use of phytoplankton biomass in these reservoirs. Scientific Messenger of Lviv National University of Veterinary Medicine and Biotechnologies. Series: Agricultural sciences, 23(95), 108-113. doi: 10.32718/nvlvet-a9516

Reservoirs and ponds belong to specific objects of water resources. Most reservoirs and ponds are of anthropogenic origin. They are of special importance for the Lviv region due to its terrestrial properties. In modern conditions, the importance of reservoirs and ponds is growing significantly. This is due to the fact that in many areas they form nuclei around which recreational complexes are formed. Reservoirs and ponds play an important role in the health and recreation of people. They are created by man to regulate runoff for commercial use of surface waters. The use of artificial reservoirs - reservoirs and ponds is carried out mainly depending on the water content and economic specialization of the regions. Therefore, it is very important to determine the quality of water in the ponds of Lviv region to establish ways of its further use. Recently, the problem of water enrichment with nutrients due to anthropogenic activity, which contributes to the growth of bioproducts of algae and other mass forms of aquatic organisms, has become especially acute. The article considers the rates of Lviv district of Krotoshyn village (№ 1, № 2) and Zhyrivka village (№ 3). The aim of the work was to determine the qualitative assessment of pond waters of Lviv region and the study of phytoplankton biomass and to determine the prospects for its use. The experimental part of the research was performed in the production laboratory at vul. Stryjska, 18a. The material for the research was water samples. The results of the analysis were compared with the list of maximum permissible concentrations (MPC) of harmful substances in water bodies in accordance with Order № 400 of 12.05.2010 on approval of State Sanitary Norms and Rules "Hygienic requirements for drinking water intended for human consumption" DSanPiN 2.2. 4-171-10). According to research, the water in the pond in the village of Zhyrivka turned out to be very dirty. Dirty water was in pond № 2 in the village of Krotoshin and polluted in the same village in pond № 1. The water in the ponds in the village of Krotoshin was pure in color. The water in the pond in the village of Zhyrivka was polluted, green and yellow. The highest $\mathrm{pH}$ level with a value of 8.8 was in the water pond in the village of Zhirivka, although it should be noted that this figure was quite high in the other two studied ponds. The lowest concentration of oxygen was in the pond in the village of Zhyrivka, the phosphate content was normal only in the water of the pond № 1 in the village of Krotoshyn. The largest amount of phytoplankton biomass was found in the village of Zhyrivka (pond № 3), which indicates pollution and "blooming" of the reservoir. This biomass can be used directly as an effective organo-mineral fertilizer.

Key words: water, ponds, phytoplankton biomass, qualitative assessment, organoleptic characteristics of water, biomass use.

\section{Оцінка якості ставкових вод Львівщини та перспективи використання бі- омаси фітопланктону цих водойм}

\author{
Н. А. Литвин, О. П. Руденко, Б. В. Гутий
}

Львівський національний університет ветеринарної медицини та біотехнологій імені С. 3. Гжицького, м. Львів, Україна 
Водосховища і ставки належать до спещифічних об'єктів водних ресурсів. Більшість водосховиш $і$ ставків є антропогенного походження. Для Львівської області через ї̈ сухопутні властивості вони мають особливе значення. У сучасних умовах суттєво зростає значення водосховищ і ставків. Зумовлено ие тим, шо в багатьох районах вони утворюють ядра, навколо яких формуються рекреаційні комплекси. Водосховища і ставки відіграють велику роль в оздоровленні та відпочинку людей. Вони створені людиною для регулювання стоку з метою господарського використання поверхневих вод. Використання шитучних водойм - водосховии $i$ ставків здійснюється, переважно, залежно від водності і господарської спеціалізації регіонів. Тому дуже важливим є визначення якості води у ставках Львівської області для встановлення шляхів ї̈ подальшого використання. Останнім часом особливо гостро постала проблема збагачення води поживними речовинами внаслідок антропогенної діяльності, щзо сприяє зростанню біопродукціі водоростей та інших масових форм гідробіонтів. У статті розглянуто ставки Львівського району села Кротошин (№ 1, № 2) та села Жирівка (№ 3). Метою роботи було визначення якісної очінки ставкових вод Львівщини й дослідження біомаси фітопланктону та визначення перспектив ї̈ використання. Експериментальна частина досліджень виконувалась у виробничій лабораторії за адресою вул. Стрийська, 18а. Матеріалом для досліджень були проби води. Результати аналізу порівнювали з переліком гранично допустимих концентрацій (ГДК) шкідливих речовин у водних об'єктах згідно з наказом № 400 від 12.05 .2010 про затвердження Державних санітарних норм та правил “Гігієнічні вимоги до води питної, призначеної для споживання людиною” (ДСанПіН 2.2.4171-10). За результатами досліджень дуже брудною виявилася вода у ставку в селі Жирівка. Брудна вода була у ставку № 2 в селі Кротошин і забруднена в тому ж селі в ставку № 1. Чистою щуодо колірності була вода у ставах в селі Кротошин - голобуватозелена. Забруднена, зелено-жовта, була вода у ставі в селі Жирівка. Найвищий рівень рН із значенням 8,8 був у воді ставку в селі Жирівка, хоча варто зазначити, щуо досить високий ией показник був і в двох інших досліджуваних ставках. Наймениа концентрачія кисню була у ставі в селі Жирівка, вміст фосфатів в нормі був лише у воді ставу № 1, щчо в селі Кротошин. Найбільша кількість біомаси фітопланктону виявлена у селі Жирівка (ставок № 3), щео свідчить про забруднення та “ивітіння” водойми. Цю біомасу можна безпосередньо використовувати як ефективне органо-мінеральне добриво.

Ключові слова: вода, ставки, біомаса фітопланктону, якісна оцінка, органолептичні показники води, використання біомаси.

\section{Вступ}

Поняття водних ресурсів включає поверхневі та підземні води на певній території та акваторію, що придатні для сільськогосподарського та промислового виробництва та відповідають загальним потребам населення (Kukurudza \& Perkhach, 2009; Lytvyn et al., 2020; Rudenko et al., 2021).

Водойми та ставки - це специфічні об'єкти водних ресурсів. Вони впливають на гідрологічні умови річок та озер і мікроклімат навколишніх територій. Використання цих об'єктів головним чином залежить від вологості району та його господарської спеціалізації. У маловодних центральних та південних районах штучні водойми в основному використовуються для водопостачання, зрошення та вирощування риби (Hidroenerhetychne osvoiennia resursiv malykh richok). У північних районах із надмірною вологістю водосховища та ставки є джерелами зволоження і водопостачання, а також можуть використовуватися для рибництва і рекреації. На Прикарпатті основним їх призначенням є водопостачання, гідроенергетика, рибництво та боротьба з повенями (Khilchevskyi \& Hreben, 2014).

Львівщина посідає четверте місце в Україні щодо кількості ставків. Всього у регіоні нараховується 3085 ставків. Ці водойми - водосховища та ставки, мають велике господарське значення, а також є важливими для водності території (Perkhach, 2018).

"Якість води" - це термін, що використовується для вираження придатності води для різного роду використання або підтримки певних процесів. Будьяке використання має певні вимоги до фізичних, хімічних або біологічних характеристик води; наприклад, обмеження концентрацій токсичних речовин для використання питної води або обмеження температур і діапазонів $\mathrm{pH}$ води для підтримки мікроорганізмів. Отже, якість води може бути визначена за допомогою ряду змінних, які обмежують використання води (Iakisna pytna voda..., 2014).

Якість води обумовлена як природними, так і антропогенними факторами. У результаті інтенсивного використання водних ресурсів змінюються якісні та кількісні показники води, складові водного балансу, гідрологічний режим водних об'єктів. Це відбувається тому, що більшість річок і озер є одночасно джерелами водопостачання й приймачами господарськопобутових, промислових i сільськогосподарських скидів (Stroi, 2021).

У зв'язку з цим при водогосподарському плануванні та регулюванні якості води необхідно брати до уваги вплив кожного 3 цих факторів окремо і всіх разом. Господарсько-побутові, промислові сільськогосподарські скиди зумовлюють хімічне, фізичне, біологічне і теплове забруднення гідросфери. Хімічне забруднення води відбувається в результаті надходження у водойми зі стічними водами шкідливих домішок неорганічного та органічного походження: сполук миш'яку, свинцю, ртуті, міді, кадмію, хрому, фтору тощо. Вони поглинаються фітопланктоном i передаються далі харчовим ланцюжком більш високоорганізованим організмам, що супроводжується кумулятивним ефектом, який полягає в прогресуючому збільшенні вмісту шкідливих сполук у кожній наступній ланці харчового ланцюжка. Більшість цих домішок $є$ токсичними для мешканців водойм.

Основними елементами моніторингу якості води є вимірювання на місці, збір та аналіз проб води, вивчення та оцінка результатів аналізу, а також звітність про результати (DSTU 7487:2013, 2014).

Останнім часом особливо гостро постала проблема збагачення води поживними речовинами унаслідок антропогенної діяльності, що сприяє зростанню біопродукції водоростей та інших масових форм гідробіонтів (Dihtiar, 2019).

Важливим є визначити якість води у ставках Львівської області для встановлення шляхів іiі подальшого використання та пошуку ефективних рішень щодо застосування біомаси фітопланктону цих водойм.

Фітопланктон як основний фотосинтезуючий компонент гідроекосистем відіграє важливу роль у формуванні хімічного складу води та запасів органічних 
речовин водойм. Він виступає індикатором екологічного стану водойми (Bazaeva et al., 2015).

Тому метою нашої роботи було визначення не лише якісної оцінки ставкових вод Львівщини, а саме двох ставків у селі Кротошин та одного - у селі Жирівка, а й дослідження біомаси фітопланктону та визначення перспектив її використання.

\section{Матеріал і методи досліджень}

Експериментальна частина наших досліджень виконувалась у виробничій лабораторії, за адресою вул. Стрийська, 18a. Лабораторія атестована згідно з вимогами законодавства (Свідоцтво про атестацію № ПТ375/20 від 28.09.2020 р.).

Матеріалом для досліджень слугували проби води 3 двох ставків (№ 1 та № 2) у селі Кротошин та одного - у селі Жирівка (№ 3) Львівського району.

Відбір проб проводили відповідно до вимог ДСанПіНу N 383/1940 “Вода питна. Гігієнічні вимоги до якості води централізованого господарськопитного водопостачання".

Результати аналізу порівнювали з переліком ГДК шкідливих речовин у водних об'єктах згідно з Наказом № 400 від 12.05.2010 про затвердження Державних санітарних норм та правил "Гігієнічні вимоги до води питної, призначеної для споживання людиною” (ДСанПіН 2.2.4-171-10).

Нами були досліджені такі показники: органолептичні (прозорість та колірність); гідрохімічні показники (величина $\mathrm{pH}$, концентрація розчиненого кисню, фосфатів, амонійний азот, нітрат-іонів та нітритів, завислі речовини); гідробіологічний показник (біомаса фітопланктону) та мікробіологічний показник чисельності бактерійної флори.

\section{Таблиця 1}

Органолептичні показники води ставків Львівського району

\begin{tabular}{|c|c|c|c|c|}
\hline Показники & $\begin{array}{c}\text { Водойма № 1, } \\
\text { с. Кротошин }\end{array}$ & $\begin{array}{c}\text { Водойма № 2, } \\
\text { с. Кротошин }\end{array}$ & $\begin{array}{c}\text { Водойма № } 3 \\
\text { с. Жирівка }\end{array}$ & Клас якості \\
\hline Прозорість, м & 0,4 & 0,16 & 0,1 & $\begin{array}{l}\text { Дуже чиста }->3 \\
\text { Чиста }-0,55-3,0 \\
\text { Забруднена }-0,35-0,5 \\
\text { Брудна }-0,15-0,3 \\
\text { Дуже брудна }-<0,1 \\
\end{array}$ \\
\hline Колір води & Голубувато-зелений & Голубувато-зелений & Зелено-жовтий & $\begin{array}{l}\text { Дуже чиста - голубуватий } \\
\text { Чиста - голубувато-зелений } \\
\text { Забруднена - зелено-жовтий, жовтий } \\
\text { Брудна - буро-жовтий } \\
\text { Дуже брудна - бурий }\end{array}$ \\
\hline
\end{tabular}

Що стосується кольору, то чистою щодо цього показника була вода у ставках (№ 1 та № 2) в селі Кротошин - голубувато-зелена. Забруднена, зелено-жовта була вода у ставі в селі Жирівка (№ 3).

Деякі види водоростей, можуть зафарбувати воду від яскраво-зеленого до бурого кольору "цвітіння" води; сполуки Феруму (Fe) придають воді зеленуватого, жовтувато-бурого відливу. Тому за кольоровістю води визначають іiі забруднення органічними або мінеральними речовинами.
Обробку отриманих результатів здійснено в комп'ютерній програмі Microsoft Excel.

\section{Результати та їх обговорення}

Одним з дієвих заходів протидії “цвітінню” ставків може бути вчасне вилучення значної частини надлишкової біомаси ціанобактерій з води $з$ іiі подальшим ефективним використанням у господарстві. Розробка та впровадження технологічного процесу виробництва метану та добрива з їхньої біомаси є однією 3 перспективних природоподібних біотехнологій, здатних зменшити гостроту проблеми “цвітіння" водойм, мінімізувати екологічні ризики та забезпечити регіон додатковими енергоресурсами (Dihtiar, 2019).

Для оцінки сучасного екологічного стану того чи іншого водного об'єкта доцільно вивчення тих компонентів водних екосистем, які можуть бути надійними показниками змін зовнішнього середовища, в тому числі й антропогенного характеру (Ekolohichna otsinka..., 2020).

Отримані результати наших досліджень якості води та кількості біомаси фітопланктону в ставках були такими. В таблиці 1 наведено результати досліджень органолептичних показників води у ставках Львівського району.

Низька прозорість води має таку перевагу, як блокування ультрафіолету, необхідного для життя підводних рослин, обмежуючи тим самим ріст деяких рослин.

Як показують результати наших досліджень, дуже брудною виявилася вода у ставку, що в селі Жирівка. Брудна вода була у ставі № 2 в селі Кротошин і забруднена в тому ж селі в ставі № 1.
Через вплив хімічних речовин на водойми якість води знижується, створюючи загрозу життю водних організмів. Тому розвиток досліджень хімії води $\epsilon$ нагальною потребою аналізу екологічного стану водойм (табл. 2).

Значення $\mathrm{pH}$ - це числове значення, яке представляє відносну кислотність або лужність води в діапазоні від 0 до 14, з нейтральним значенням 7. Якщо $\mathrm{pH}$ нижче ніж 7 - це кисла вода. Якщо рН вище ніж 7, цю воду називають лужною. 
Більшість ставків мають рН від 6,5 до 9. Значення $\mathrm{pH}$ у водоймі коливається щодня і визначається скла- дною залежністю між вуглекислим газом, жорсткістю води, лужністю, фотосинтезом та наявністю кисню.

Таблиця 2

Гідрохімічні показники води ставків Львівського району

\begin{tabular}{|c|c|c|c|c|}
\hline Показники & $\begin{array}{l}\text { Водойма № 1, } \\
\text { с. Кротошин }\end{array}$ & $\begin{array}{c}\text { Водойма № 2, } \\
\text { с. Кротошин }\end{array}$ & $\begin{array}{c}\text { Водойма № } 3 \\
\text { с. Жирівка }\end{array}$ & гдК \\
\hline $\mathrm{pH}$ & 8,05 & 8,0 & 8,8 & $6,5-8,5$ \\
\hline Жорсткість, моль/л & 7,1 & 7,2 & 6,2 & $2,0-6,0$ \\
\hline Загальний кисень, мг/л & 5,5 & 4,9 & 2,7 & Від 5,0 \\
\hline Фосфати & 0,5 & 0,7 & 2,3 & До 0,5 \\
\hline Аміак & Н.в. & Н.в. & 3,1 & сліди \\
\hline Нітрат-іони & 1,5 & 1,9 & 2,1 & До 2,0 \\
\hline Нітрити & 0,02 & 0,02 & 0,06 & До 0,05 \\
\hline Зависи, мг/л & 16 & 20 & 45 & $\begin{array}{c}\text { Дуже чиста }-<5 \\
\text { Чиста }-5-14 \\
\text { Забруднена }-15-30 \\
\text { Брудна }-31-100 \\
\text { Дуже брудна -> } 101\end{array}$ \\
\hline
\end{tabular}

Невідповідне значення рН призведе до негативних наслідків для водойми. Значення $\mathrm{pH}$ протягом дня також змінюється. Коли рослини вночі виділяють вуглекислий газ, рН падає, а вода стає більш кислою. Протягом дня, коли рослини використовують вуглекислий газ при фотосинтезі, вода стає лужною, а значення рН підвищується. Значення рН також впливає на кількість корисних бактерій та процес розкладання органічних залишків у водоймі. Більшість бактерій не можуть вижити у кислій воді.

Найвищий рівень $\mathrm{pH}$ зі значенням 8,8 води у ставку в селі Жирівка (№ 3), хоча варто зазначити, що досить високий цей показник був і в двох інших (№ 2, № 1) досліджуваних ставках.

Сума розчинених у воді двовалентних іонів - це жорсткість води. Найпоширенішими причинами високої жорсткості води є карбонат Сa i Mg. Жорстка вода може обмежити зростання планктону і риби у ставку. Як показують наші дослідження, показник жорсткості був перевищений у воді всіх трьох ставках, а найбільше у ставку № 2 в селі Кротошин.

Загальний кисень $\left(\mathrm{O}_{2}\right)$ належить до найважливіших гідрохімічних показників, які впливають на екологічний стан водойм, зокрема ставків. Його концентрація в більшості визначає якість води завдяки інтенсифікації процесів самоочищення і гідробіологічного кругообігу речовин. Кисневий режим має дуже великий вплив на життя водойми. Визначення кисню в поверхневих водах є необхідним для спостереження за умовами існування гідробіонтів та розвитку рослинності (Maltsev et al., 2011).

Результати наших досліджень показали, що найменша концентрація кисню була у ставку, що в селі Жирівка (№ 3), і становила 2,7 мг/л, допустимий рівень кисню був у ставку № 1 в селі Кротошин і становив 5,5 мг/л.

Фосфор (Р) - один з найважливіших елементів, необхідних живим організмам. Він сам собою не токсичний. Проблеми виникають, коли надлишок фосфору скидається в природні водойми. Це призведе до евтрофікації - прискореного зростання водоростей, а відтак - до дисбалансу в екосистемі водойми. Резуль- татом може бути те, що умови життя риб погіршуються через значне зниження кисню.

Результати наших досліджень показують, що вміст фосфатів в нормі був лише у воді ставку № 1, що в селі Кротошин. Значно перевищив норму вміст фосфатів у 4,6 раза у ставку № 3 , що знаходився в селі Жирівка.

Аміак (N) існує у воді у вигляді амонійної солі. У поверхневих водах амонійний азот утворюється на першій стадії мінералізації азотовмісних амонійних матеріалів.

Концентрація аміаку була перевищена у ставку № 3 в селі Жирівка і становила 3,1 мг/л, в ставках № 1 i № 2 в селі Кротошин знайдено сліди аміаку. Високий вміст амонійного азоту у водоймах призводить до отруєння гідробіонтів, оскільки вільний Аміак є для них сильною отрутою.

Незначно був перевищений вміст Нітрат-іонів у ставку в селі Жирівка (№ 3).

Під дією ультрафіолету, розряду блискавки або поновлення нітратів у підземних водах утворюється невелика кількість нітритів (нітратів) у поверхневих водах. У ставку села Жирівка їхній вміст трохи перевищує норму. Збільшення вмісту нітритів вказує на те, що розкладання органічних речовин посилюється за умови повільного окислення $\mathrm{NO}_{2}^{-}$до $\mathrm{NO}_{3}^{-}$, що свідчить про забруднення водойми і $є$ важливим показником здоров'я.

Що стосується завислих речовин, то за показником чистоти забрудненою була вода в ставках № 1, та № 2, що в селі Кротошин, а брудною вона була в ставку № 3, що в селі Жирівка.

Про ступінь розвитку планктону можна судити за кольором води, який визначається стандартом, шляхом занурення індикаторного диску в половину прозорості індикатора. Гідробіологічна оцінка (табл. 3) якості вод дозволяє: визначити екологічний стан водних об'єктів; оцінити якість вод як середовища мешкання живих організмів; визначити сукупний ефект впливу забруднювальних речовин; перевірити наявність вторинного забруднення.

Найбільша кількість біомаси фітопланктону виявлена нами в селі Жирівка (ставок № 3), що свідчить 
про забруднення та “цвітіння” водойми. Як свідчать дані таблиці 3, чисельність біомаси фітопланктону перевищувала у ставку села Жирівка у 5,5 раза порів- няно зі ставком № 1, що в селі Кротошин, і в 6,8 раза порівняно зі ставком № 2 в тому ж селі.

Таблиця 3

Гідробіологічні показники води ставків Львівського району

\begin{tabular}{lccc}
\hline \multicolumn{1}{c}{ Показники } & $\begin{array}{c}\text { Водойма № 1, } \\
\text { с. Кротошин }\end{array}$ & $\begin{array}{c}\text { Водойма № 2, } \\
\text { с. Кротошин }\end{array}$ & $\begin{array}{c}\text { Водойма № 3 } \\
\text { с. Жирівка }\end{array}$ \\
\hline Біомаса фітопланктону, мг/л & 3,9 & 4,6 & 14,2 \\
Чисельність бактерійної флори, млн. КУО/мл & 1,5 & 1,2 & 8,2 \\
\hline
\end{tabular}

Біоту зарегульованих водойм слід розглядати в трьох основних аспектах: як природний ресурс, як індикатор екологічного стану і як чинник формування якості води (Maltsev et al., 2011).

Значну частину біомаси фітопланктону становлять планктонні водорості, яким властивий високий ступінь реакції на зміну параметрів середовища за порівняно короткий проміжок часу (Dihtiar, 2019). Значення планктонних водоростей зумовлене їхньою участю в різноманітних трофічних зв'язках, сукупність яких визначає загальну біологічну продуктивність водних екосистем, а також здатність водойм до самоочищення. Тому планктонні водорості часто використовуються як види-біоіндикатори забруднення водного середовища різними полютантами (Shcherbak \& Semeniuk, 2004).

Щороку в літній період ставкова вода в селі Жирівка перетворюється на джерело небезпечного мікробного забруднення. У такій ситуації, коли не можна усунути надмірного надходження поживних речовин у цей ставок, лише щорічне вилучення основної маси ціанобактерій разом 3 поживними речовинами, що вони увібрали, може поліпшити екологічний стан ставка № 3 .

Як показують дані, цю біомасу можна безпосередньо використовувати як ефективне органо-мінеральне добриво. Піддавання біомаси ціанобактерій анаеробній ферментації дозволяє одержати біогазову суміш 3 високим вмістом метану, а залишки біомаси можуть бути успішно використані як добриво в аграрному виробництві та лісогосподарській галузі (Dihtiar et al., 2016).

Отже, регулярне вилучення ціанобактерій зі ставків села Кротошин та Жирівка Львівського району в літній період приноситиме не лише екологічну, а й економічну (енергетичну й аграрну) користь для цих населених пунктів.

\section{Висновки}

1. Дуже брудною виявилася вода у ставку, що в селі Жирівка. Брудна вода була у ставку № 2 в селі Кротошин і забруднена в тому ж селі у ставку № 1.Чистою щодо колірності була вода у ставах в селі Кротошин - голобувато-зелена. Забруднена, зеленожовта, була вода у ставі в селі Жирівка.

2. Найвищий рівень $\mathrm{pH}$ зі значенням 8,8 був у воді ставка в селі Жирівка, хоча варто зазначити, що досить високий цей показник був і в двох інших досліджуваних ставках. Показник жорсткості був пере- вищений у воді всіх трьох ставків, а найбільше у ставі № 2 в селі Кротошин. Найменша концентрація кисню була у ставі, що в селі Жирівка, і становила 2,7 мг/л, допустимий рівень кисню був у ставі № 1 в селі Кротошин і становив 5,5 мг/л.

3. Уміст фосфатів в нормі був лише у воді ставу № 1, що в селі Кротошин. Значно перевищив норму вміст фосфатів: у 4,6 раза в ставі № 3, що в селі Жирівка. Концентрація аміаку була перевищена у ставі № 3 в селі Жирівка і становила 3,1 мг/л, в ставах № 1 i № 2 в селі Кротошин знайдено сліди аміаку. Незначно був перевищений вміст нітрат-іонів у ставку в селі Жирівка.

4. За показником чистоти забрудненою була вода в ставах № 1, та № 2, що в селі Кротошин, а брудною вона була в ставі № 3, що в селі Жирівка.

5. Чисельність бактерійної флори перевищувала у ставі Жирівка в 5,5 раза порівняно зі ставом № 1, що в селі Кротошин і в 6,8 раза порівняно зі ставом № 2 в тому ж селі.

\section{References}

Bazaeva, A., Chuzhma, N., \& Savenko, N. (2015). Fitoplankton vyroshchuvalnoho stavu za umov vnesennia orhanichnoho dobryva URL: https://www.zoology. dp.ua/z15_043.html (in Ukrainian).

Dihtiar, S. V. (2019). Rozrobka biotekhnolohii pererobky masovykh form hidrobiontiv: avtoreferat. Odesa (in Ukrainian).

Dihtiar, S., Pasenko, A., \& Pasenko, D. (2016). Eksperymentalnyi syntez biohazu na osnovi biomasy tsianei. Materialy III Mizhnarodnoi naukovopraktychnoi konferentsii "Ekolohiia i pryrodokorystuvannia $\mathrm{v}$ systemi optymizatsii vidnosyn pryrody $\mathrm{i}$ suspilstva". Ternopil (in Ukrainian).

DSTU 7487:2013 (2014). Yakist vody. Metod vyznachennia mikromitsetiv $u$ vodi. Kyiv: Minekonomrozvytku Ukrainy (in Ukrainian).

Ekolohichna otsinka stanu hidroekosystemy za vydovym bahatstvom fitoplanktonu, 2020. URL: https://webcache.googleusercontent.com/search?q=cac he:otVUcR4aiKQJ:https://nupp.edu.ua/uploads/files/0 /events/other/2020/02/ii-tur (in Ukrainian).

Hidroenerhetychne osvoiennia resursiv malykh richok. URL: http://ua.textreferat.com/referat-4418-2.html (in Ukrainian).

Iakisna pytna voda - osnova zdorovia liudyny: mystetstvo likuvannia (2014). Zhurnal suchasnoho likaria, 2, 40-42. 
https://www.health-medix.com/articles/misteztvo/201404-20/yakisna_pitna.pdf (in Ukrainian).

Khilchevskyi, V. K., \& Hreben, V. V. (2014). Vodnyi fond Ukrainy: Shtuchni vodoimy - vodoskhovyshcha i stavky: dovidnyk. Kyiv: Interpres (in Ukrainian).

Kukurudza, S. I., \& Perkhach, O. R. (2009). Vykorystannia ta okhorona vodnykh resursiv. Lviv: LNU imeni Ivana Franka (in Ukrainian).

Lytvyn, N., Rudenko, O., \& Gutyj, B. (2020). Assessment and prospects of development of ecological and tourist potential of Busk district of Lviv region. Scientific Messenger of LNU of Veterinary Medicine and Biotechnologies. Series: Agricultural Sciences, 22(92), 81-86. doi: 10.32718/nvlvet-a9214.

Maltsev, V. I., Karpova, H.O., \& Zub, L. M. (2011). Vyznachennia yakosti vody metodamy bioindykatsii: naukovo-metodychnyi posibnyk. K.: Naukovyi tsentr ekomonitorynhu ta bioriznomanittia mehapolisu NAN Ukrainy, Nederzhavna naukova ustanova Instytut ekolohii (INEKO) Natsionalnoho ekolohichnoho tsentru Ukrainy (in Ukrainian).
Perkhach, O. R. (2018). Vykorystannia resursiv vodoskhovyshch ta stavkiv Lvivskoi oblasti. Pryrodni resursy rehionu: problemy vykorystannia, revitalizatsii ta okhorony: mater. mizhnar. nauk. sem. (Lviv, 5-7 zhovtnia 2018 r.). Lviv, 282-287 (in Ukrainian).

Rudenko, O., Lytvyn, N., \& Gutyj, B. (2021). Assessment of microbiological indicators and monitoring of a sociological survey of the quality of sources in the city of Lviv. Scientific Messenger of LNU of Veterinary Medicine and Biotechnologies. Series: Agricultural Sciences, 23(94), 81-85. doi: 10.32718/nvlvet-a9415.

Shcherbak, V. I., \& Semeniuk, N. Ie. (2004). Formuvannia struktury fitoplanktonu $\mathrm{v}$ zalezhnosti vid antropohennoho zabrudnennia. Hidrolohiia, hidrokhimiia i hidroekolohiia, 6, 300-305 (in Ukrainian).

Stroi, D. (2021). Ekolohichna bezpeka ta zakhyst vodnykh obiektiv vid antropohennoho vplyvu promyslovykh pidpryiemstv mista Melitopolia ta Zaporizkoi oblasti. URL: $\quad$ http://elar.tsatu.edu.ua/bitstream/123456789/ 14871/1/Строй\%2010.pdf (in Ukrainian). 